UDK 577.1 : 61

ISSN 1452-8258

\title{
DIAGNOSTIC BENEFITS OF MINDIN AS A PROSTATE CANCER BIOMARKER
}

$$
\text { DIJAGNOSTIČKE PREDNOSTI MINDINA KAO BIOMARKERA RAKA PROSTATE }
$$

\author{
Lenka Hanousková1, Jakub Řezáč , Štěpán Veselý , Richard Prǔša1, Karel Kotaška1 \\ ${ }^{1}$ Department of Medical Chemistry and Clinical Biochemistry, Charles University, Second Faculty of Medicine \\ and University Hospital Motol, Prague, Czech Republic \\ ${ }^{2}$ Department of Urology, Charles University Second Faculty of Medicine and University Hospital Motol, Prague, \\ Czech Republic
}

\begin{abstract}
Summary
Background: It has been shown that decreased expression and activity of extracellular matrix protein mindin correlate with various types of cancers including breast, colon and lung cancers. The aim of the presented study was to investigate the serum mindin levels in prostate cancer.

Methods: Mindin concentrations in serum were measured in 56 patients with prostate cancer (mean age 68 years) and in control group of 29 healthy men (mean age 64 years) using commercially available enzymatic immunoassay (Cusabio, WuHan, China). The patients were divided with respect to the severity of the disease into two groups according to the EAU guidelines (stage 1, 2 - less severe tumours, stage 3, 4 - severe tumours).

Results: Serum mindin concentrations were significantly elevated in the group of healthy individuals unlike in the patients with prostate cancer $(2.12 \mathrm{ng} / \mathrm{mL}$ vs $0.78 \mathrm{ng} / \mathrm{mL}$, with $\mathrm{P}=0.0007, \mathrm{AUC}=0.705)$. Patients with less severe tumours (stage 1,2) and severe tumours (stage 3,4) had significantly decreased levels of $\mathrm{S}$-mindin as well $(P=0.0037)$, although the difference in serum mindin concentrations between the patients with less severe and severe tumours was not significant.

Conclusions: Concentrations of mindin were decreased in patients with prostate cancer and reduced in patients with less severe prostate cancer as well. Mindin appears to be a promising diagnostic marker useful in the diagnosis of prostate cancer.
\end{abstract}

Keywords: mindin, prostate cancer, biomarker

Address for correspondence:

Karel Kotaška

Department of Medical Chemistry and Clinical Biochemistry

2nd Faculty of Medicine, Charles University

University Hospital Motol

$\checkmark$ Uvalu 84

15006 Prague 5

\section{Kratak sadržaj}

Uvod: Pokazalo se da je smanjena ekspresija i aktivnost ekstracelularnog proteinskog matriksa mindina korelira sa različitim tipovima raka, uključujući rak dojke, debelog creva i pluća. Cilj prikazane studije je bio da se ispita serumski nivo mindina kod karcinoma prostate.

Metode: Koncentracije mindina u serumu su merene kod 56 bolesnika sa karcinomom prostate (srednja starost 68 godina) i u kontrolnoj grupi od 29 zdravih muškaraca (srednja starost 64 godine) korišćenjem komercijalno dostupnog enzimskog testa (Cusabio, VuHan, Kina). Pacijenti su prema težini bolesti podeljeni u dve grupe prema EAU smernicama (faza 1, 2 - manje teški tumori, faza 3, 4 - teški tumori).

Rezultati: Koncentracije serumskog mindina bile su značajno povišene u grupi zdravih pojedinaca, za razliku od pacijenata sa rakom prostate $(2,12 \mathrm{ng} / \mathrm{mL}$ u odnosu na $0,78 \mathrm{ng} / \mathrm{mL}$, sa $\mathrm{P}=0,0007, \mathrm{AUC}=0,705)$. Pacijenti sa manje ozbiljnim tumorima (faza 1,2) i teškim tumorima (faza 3,4) imali su i značajno snižene nivoe S-mindina $(P=0,0037)$, iako razlika u koncentracijama mindina $u$ serumu izme u pacijenata sa manje teškim i ozbiljnim tumori nije bila značajna.

Zaključak: Koncentracije mindina su smanjene kod pacijenata sa rakom prostate, a smanjene su i kod pacijenata sa manje teškim oblikom raka prostate. Izgleda da je mindin obećavajući dijagnostički marker i da je koristan u dijagnostici raka prostate.

Ključne reči: mindin, rak prostate, biomarker

List of abbreviations: AUC, Area under the curve; CV, Coefficient of variation; EAU, European Association of Urology; ELISA, Enzyme-linked immunosorbent assay; IQR, interquartile range; $\mathrm{Pca}$, prostate carcinoma; $\mathrm{PHI}$, prostate health index; PSA, Prostate-specific antigen; PSADT, Prostatespecific antigen doubling time; ROC, Receiver operating characteristics. 


\section{Introduction}

Prostate cancer ( $\mathrm{PCa}$ ) is one the most frequently diagnosed tumours of men and the third most common cause of cancer death of Czech men (1). Currently, the only biomarker in wide clinical use for the diagnosis and prognosis of prostate cancer is the prostate-specific antigen (PSA). Other markers useful for the diagnostics of prostate cancer are free PSA and Free/Total PSA ratio, complexed PSA, pro PSA 2proPSA and Prostate Health Index (PHI). Total PSA, $\%$ fPSA, f/tPSA, and other PSA derivatives, PSAD, PSA velocity, PSADT, age-specific PSA do not decrease the number of unnecessary biopsies performed for diagnostic purposes. Despite all of these markers, a 100\% conclusively precise diagnostic test for PCa has not been introduced yet (2).

PSA can be detected in the serum of a blood sample and is considered to be currently the most useful tumour marker (3). PSA can be used for prostate cancer screening and monitoring of the response to the treatment. PSA seems to be useful for the detection of prostate cancer of the men whose total PSA concentration in the $4-10 \mu \mathrm{g} / \mathrm{L}$ range (4). Investigation of the serum PSA levels does not have a direct correlation with increasing grade and stage of prostate cancer (5). $20 \%$ of patients have PSA levels less than $4 \mu \mathrm{g} / \mathrm{L}, 25 \%$ of the patients have PSA levels in the interval of 4-10 $\mu \mathrm{g} / \mathrm{L}$. Moreover, some aggressive forms of prostate cancer can be PSA negative (6). Due to the limitations of PSA as a biomarker, there is still a need for new biomarkers that can be used as prognostic indicators of prostate cancer for effective differentiation between indolent and aggressive disease (7).

Mindin, also called spondin 2, is an extracellular matrix protein which is encoded by the SPO2 gene located in the chromosome 4p16.3. Spondin 2 belongs to the F-spondin family of secreted extracellular matrix proteins. The members of F-spondin family have three domains: FS1 (for F-spondin), FS, and thrombospondin type 1 repeats. Mindin exerts a broad spectrum of effects on the innate immune system and its role in cancer is currently investigated (8). Recently, mindin is mentioned as a candidate biomarker for prostate cancer diagnosis (9).

The study aimed to investigate serum levels of mindin as a potential diagnostic biomarker in patients with prostate cancer.

\section{Materials and Methods}

Serum samples of patients with prostate cancer were obtained in the morning before prostatectomy. The cancer diagnosis was performed by histological examination of tumour specimens obtained by prostate resection. The samples of patients and healthy individuals were frozen immediately, aliquoted and kept at $-70{ }^{\circ} \mathrm{C}$ until mindin was analyzed. Serum concentrations of mindin were measured in 56 patients (mean age 68 years, range 45-82 years) with prostate cancer, and in the control group consisting of 29 healthy men (mean age 64 years, range 55-78 years). Informed consent was obtained for all of the individuals included in the study. The characteristics of the patients and healthy subjects are summarized in Table $I$.

Serum mindin levels were assayed using commercially available immunoassay technique ELISA kit (Cusabio, WuHan, China). The analytic characteristics of the diagnostic kit were as follows: detection limit $0.78 \mathrm{ng} / \mathrm{mL}$ and working range $3.12-200 \mathrm{ng} / \mathrm{mL}$, with a mean coefficient of variation $(\mathrm{CV})=11 \%$. The patients were previously clinically investigated and classified according to the European Association of Urology (EAU) guidelines (10). For further investigation, the patients were divided into two groups according to the severity of the disease. The first group consisted of patients with less severe tumours (stages 1 and 2), the second group consisted of patients with severe tumours (stages 3 and 4).

\section{Results}

Differences between subgroups were tested for statistical significance by the nonparametric MannWhitney test. The value of $\mathrm{P}<0.005$ was considered statistically significant. Receiving operation analysis (ROC) was used to investigate the diagnostic efficiency. The analysis of variance was used to evaluate the relationship of mindin levels with the age and PSA levels. Statistical software MedCalc version: 18.02.01 (Ostende, Belgium) was used for statistical analysis.

Serum levels of mindin in patients with prostate cancer were significantly decreased in the control group expressed as medians $(2.12 \mathrm{ng} / \mathrm{mL}$ vs 0.78 $\mathrm{ng} / \mathrm{ml}, \mathrm{P}=0.0007$, Mann-Whitney test, Figure 1). Diagnostic efficiency of serum mindin expressed as AUC calculated from the ROC analysis was 0.705 (specificity $=73 \%$ and sensitivity=64\%) (Figure 2). Serum levels of mindin in patients with less severe tumours (stages 1 and 2) and severe tumours (stages 3 and 4) were significantly decreased compared with the control group as well. $(P=0.0037$, One-way analysis of variance, Figure 3).

\section{Discussion}

The results of the pilot study confirm the relevant role of mindin in the prostate cancer diagnosis. We proved that the serum levels of mindin were significantly decreased in patients with prostate cancer compared with healthy individuals. These results differ from the results of other studies showing elevated mindin levels in patients with prostate cancer 


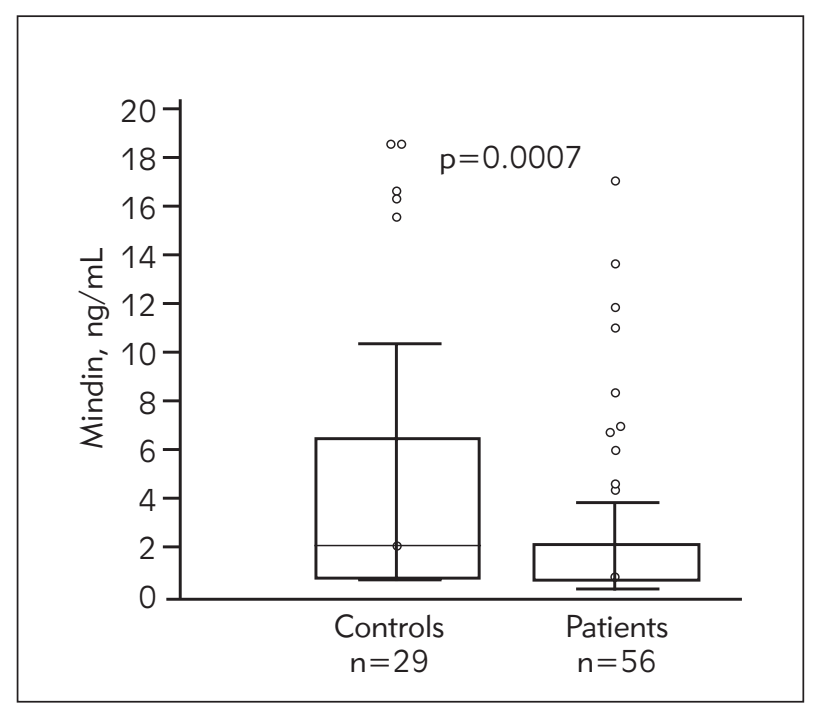

Figure 1 Serum mindin levels in healthy individuals and patients with prostate cancer.

Results are expressed as Box-and-whisker plots with medians (IQR 25. - 75. percentile).

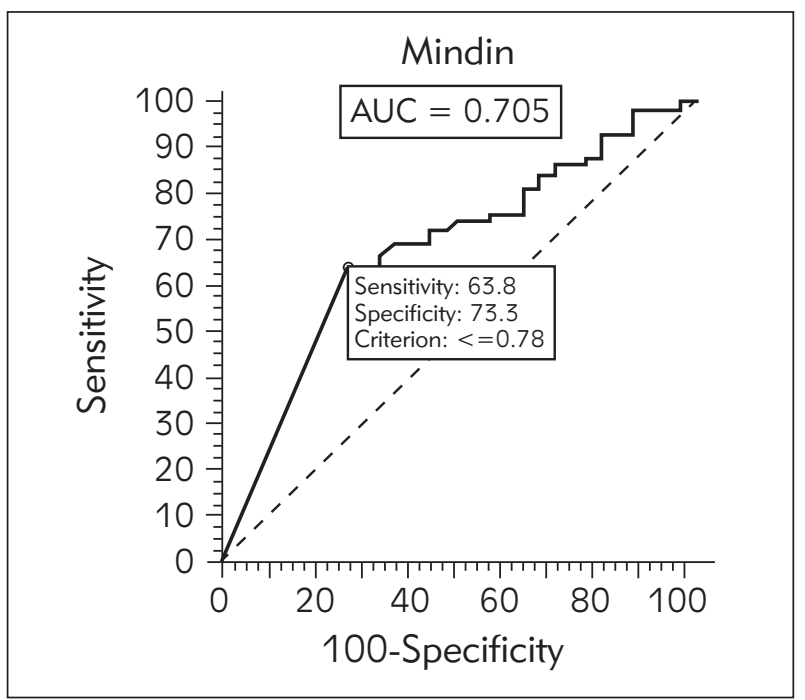

Figure 2 Diagnostic efficiency of mindin.

$(11,12,14)$. Presented results are in concordance with the study of Wang et al. (8) showing significantly decreased serum mindin in tumour lesions of patients compared with adjacent control tissues by colon, lung, gastric, oesophageal, and breast cancer. Wang et al. (8) mentioned an important role of EGR-1, which directly regulates mindin expression at the transcriptional level, and this regulates both mindin mRNA and protein expression in vitro to further define EGR-1 mediated regulation of mindin expression. The relationship between EGR-1 expression and prostate cancer was previously mentioned. Gregg et al. (12) showed that EGR-1 is downregulated in patients with prostate carcinoma according to their

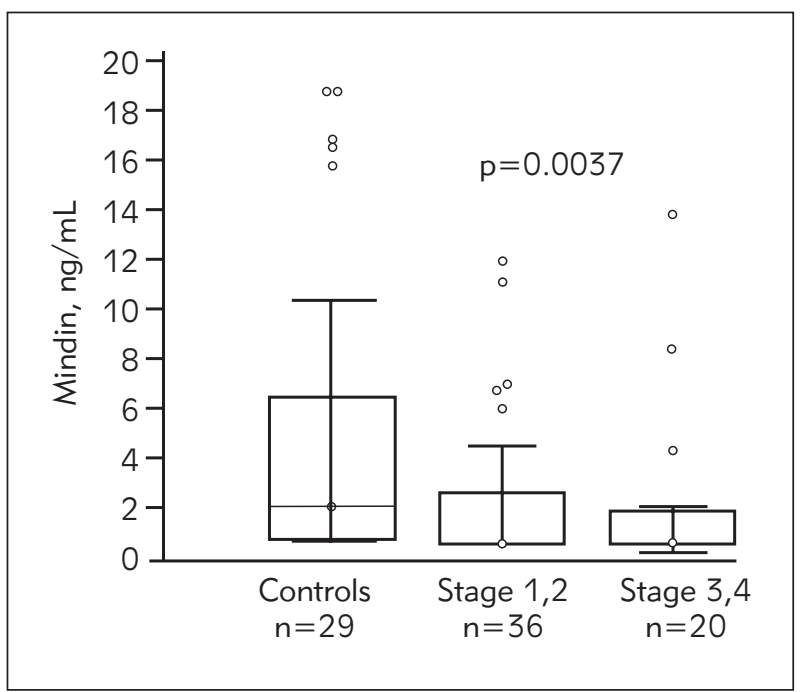

Figure 3 Serum mindin levels in patients with less severe and severe prostate cancer tumours.

Results are expressed as Box-and-whisker plots with medians (IQR 25. - 75. percentile)

Stage 1, 2 - patients with less severe tumours

Stage 3, 4 - patients with severe tumours

clinical considerations (18 of 20 patients in pT2 and pT3 clinical stages showed normal or downregulated EGR-1 expression). Contrary to the previously mentioned reports of Wang et al. (8) and Gregg et al. (12), studies of other authors showed that in patients with prostate cancer EGR-1 stimulates tumour cell growth and its expression level increases with the degree of malignancy $(11,13)$. This seems to be specific to the prostate tumour cells because, in mammary and lung tumours as well as most normal tissues, EGR-1 expression is low. This contradictory findings regarding EGR-1 expression confirmed the bivalent role of EGR-1 either as a tumour suppressor or oncogene with respect to EGR-1 regulation and the degree of the malignancy.

Our results show good diagnostic sensitivity of mindin with AUC of 0.705 . We prove that serum mindin levels are not dependent on the PSA levels, and the age $(P=0.42$, analysis of variance). The serum levels of mindin differ in patients with prostate cancer. We found significant differences between serum mindin concentrations related to the staging of cancer. The patients with less severe tumours belonging to stages 1 and 2 had lower serum mindin level than patients with severe tumours stages 3 and 4 as shown in Figure 3. These results correlate with the results found in other cancer types presented by Wang et al., (8) who presented decreased levels in patients with less severe tumours belonging to stages 1 and 2. In our study, the difference between patients in stages 1 and 2 and 3 and 4 is not significant.

The presented study is a pilot study, and thus the results need to be confirmed on a large number of samples. Various enzymatic immunoassays used for 
mindin evaluation show discrepant results, as indicated in the presented study and the study of Wang et al. (8) with similar results, which are different from the study of Luccarelli et al. (14). This finding seems to indicate that the concentrations of mindin in patients with prostate cancer are assay dependent.

The concentration of mindin is decreased in patients with prostate cancer. Mindin concentration is not related to the age and PSA levels. Mindin appears to be a promising diagnostic marker useful in the diagnosis of prostate cancer.

\section{References}

1. Geryk E, Dítě $P$, Kozel J, Štampach R, Kubíček P, Odehnal $\mathrm{J}$ : Other primary neoplasm in patients with prostate cancer in comparison of its incidence, mortality and prevalence. Onkologie 2010, 4(2): 89-94.

2. Ayyildiz SN, Ayyildiz A: PSA, PSA derivatives, proPSA and prostate health index in the diagnosis of prostate cancer. Turk J Urol 2014, 40(2): 82-88.

3. Bickers B, Aukim-Hastie C: New molecular biomarkers for the prognosis and management of prostate cancerthe post PSA era. Anticancer Res 2009, 29(8): 328998.

4. Buhmeida A, Pyrhonen S, Laato M, Collan Y: Prognostic factors in prostate cancer. Diagn Pathol 2006, 1:4.

5. Shariat SF, Canto El, Kattan MW, Slawin KM: Beyond prostate-specific antigen: new serologic biomarkers for improved diagnosis and management of prostate cancer. Rev Urol 2004, 6(2): 58-72.

6. Pryor MB, Schellhammer PF: The pursuit of prostate cancer in patients with a rising prostate-specific antigen and multiple negative transrectal ultrasound-guided prostate biopsies. Clin Prostate Cancer 2002, 1(3): 172-6.

7. Jelić M, Mandić A, Kladar N, Sudji J, Božin B, Srdjenović B. Lipid Peroxidation, Antioxidative Defense and Level of 8-Hydroxy-2-Deoxyguanosine in Cervical Cancer Patients. J Med Biochem 2018; 37: 336-45.
Acknowledgements. Supported by the project (Ministry of Health, Czech Republic) for conceptual development of research organization 00064203 (University Hospital Motol, Prague, Czech Republic).

\section{Conflict of interest statement}

The authors stated that they have no conflicts of interest regarding the publication of this article.
8. Wang LF, Liu YS, Yang B, Li P, Cheng XS, Xiao CX, Liu JJ, Li S, Ren JL, Guleng B: The extracellular matrix protein mindin attenuates colon cancer progression by blocking angiogenesis via Egr-1-mediated regulation. Oncogene 2018, 37(5): 601-15.

9. Qian X, Li C, Pang B, Xue M, Wang J, Zhou J: Spondin2 (SPON2), a more prostate-cancer-specific diagnostic biomarker. PLoS One 2012, 7(5): e37225.

10. Heidenreich A, Aus G, Bolla M, Joniau S, Matveev VB, Schmid HP, Zattoni F: EAU guidelines on prostate cancer. Eur Urol 2008, 53(1): 68-80.

11. Gitenay D, Baron VT: Is EGR1 a potential target for prostate cancer therapy? Future Oncol 2009, 5(7): 9931003.

12. Gregg JL, Brown KE, Mintz EM, Piontkivska H, Fraizer GC: Analysis of gene expression in prostate cancer epithelial and interstitial stromal cells using laser capture microdissection. BMC Cancer 2010 10:165.

13. Parra E, Ortega A, Saenz L: Down-regulation of Egr-1 by siRNA inhibits growth of human prostate carcinoma cell line PC-3. Oncol Rep 2009, 22(6): 1513-8.

14. Lucarelli G, Rutigliano M, Bettocchi C, Palazzo S, Vavallo A, Galleggiante V, Trabucco S, Di Clemente D, Selvaggi FP, Battaglia $M$ et al.: Spondin-2, a secreted extracellular matrix protein, is a novel diagnostic biomarker for prostate cancer. J Urol 2013, 190(6): 2271-7. 